
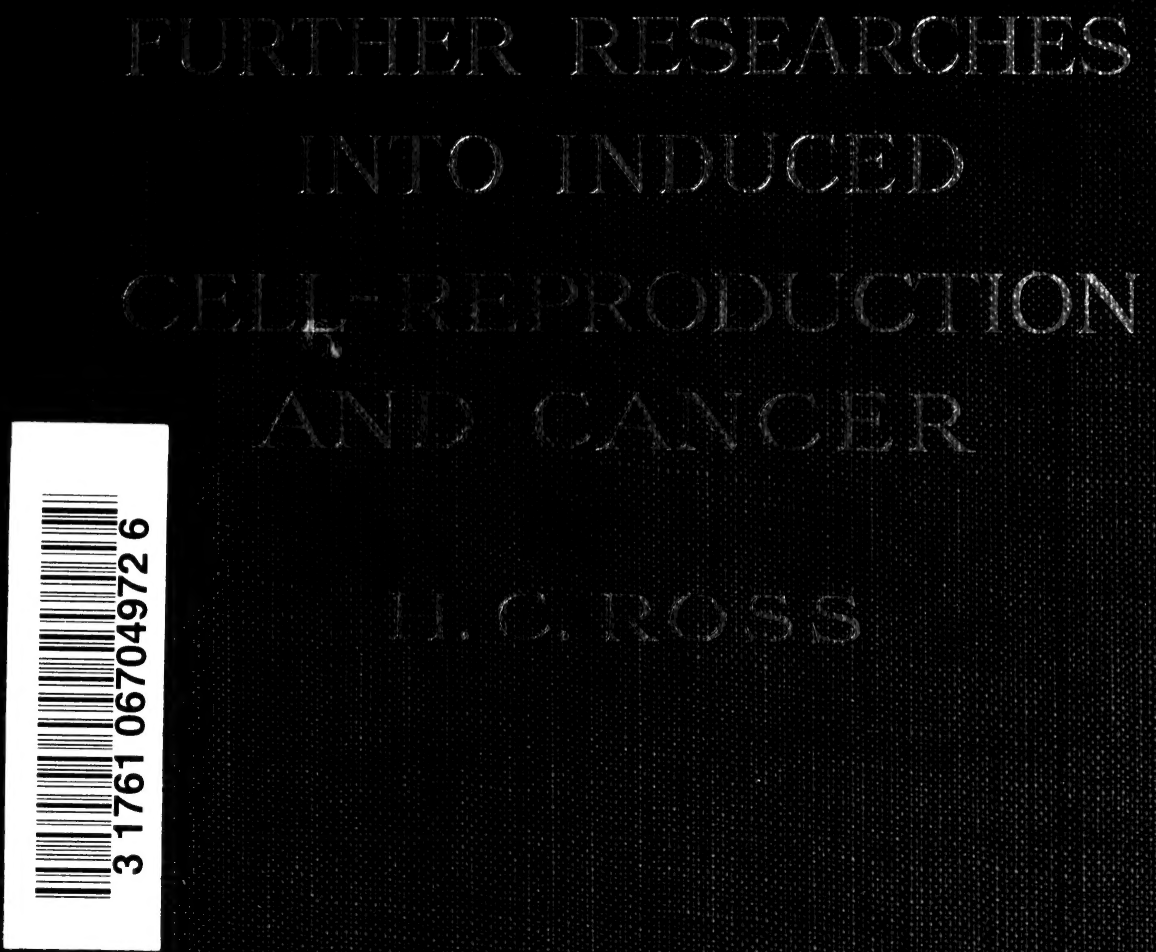

THE MOWADMUN IRSWARCHES 


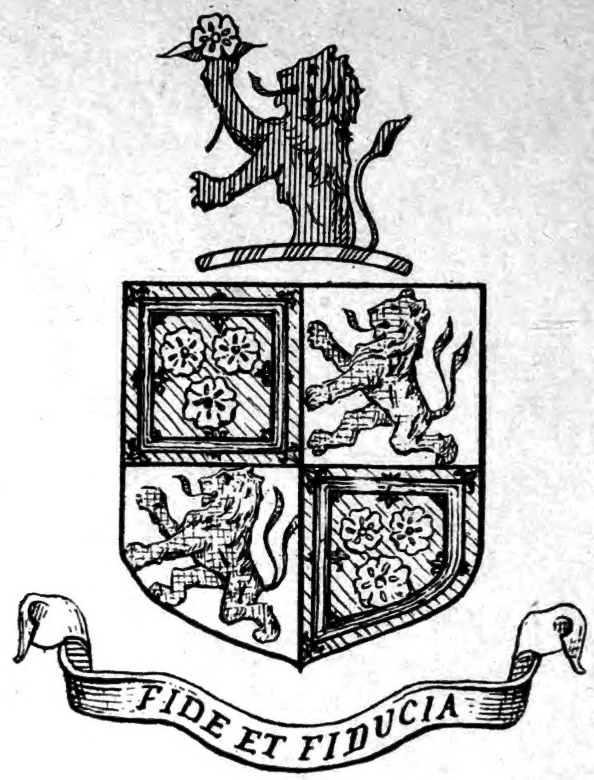

ALEXANDER PRIMROSE C.B. 
Pencened 7 ct 10,1912 



\section{FURTHER RESEARCHES}

$$
\text { INTO }
$$

INDUCED CELL-REPRODUCTION AND CANCER 


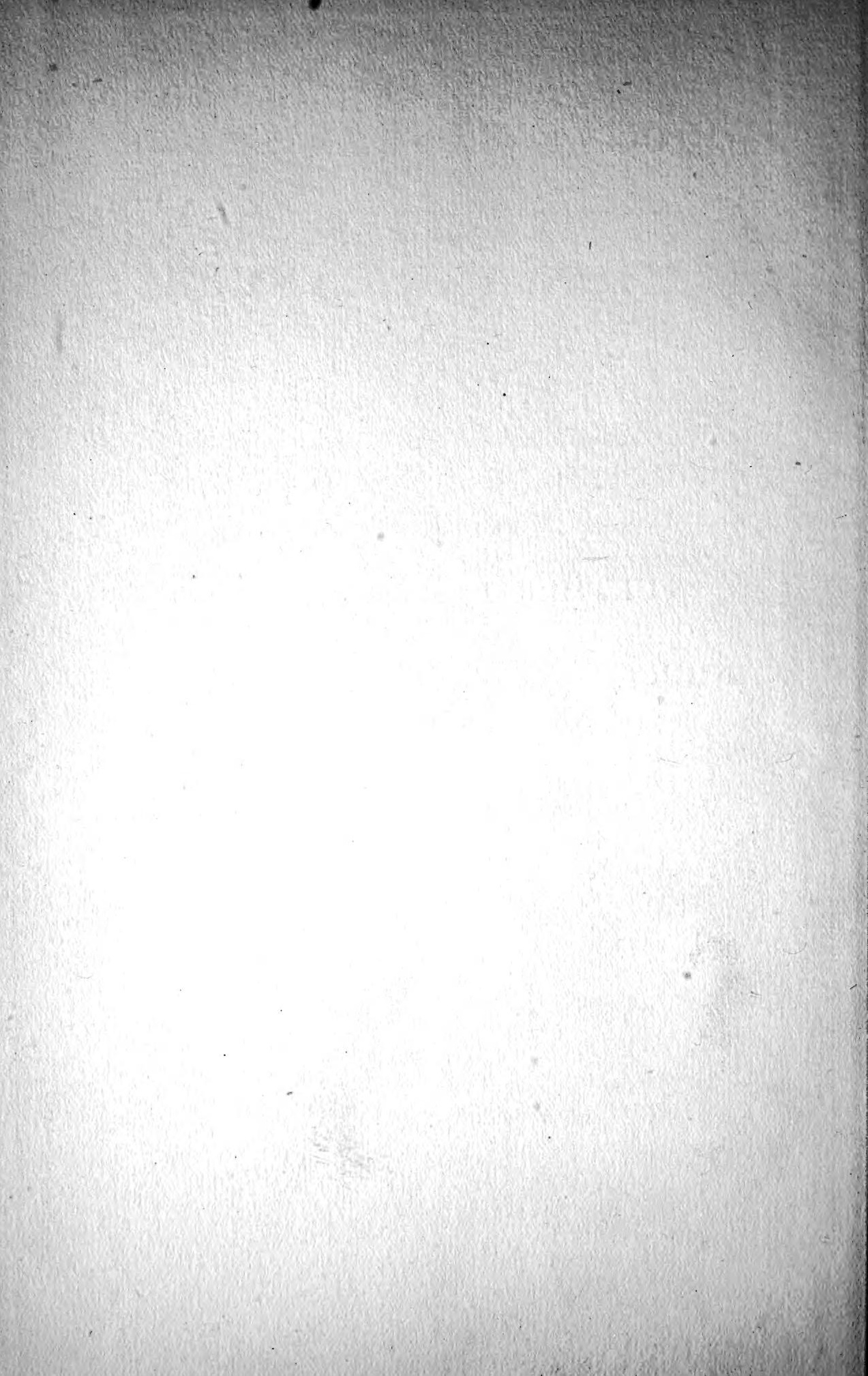
(2. thestis 


\section{MP}

$R$

\section{FURTHER RESEARCHES} INTO

\section{INDUCED CELL-REPRO- DUCTION AND CANCER}

WITH ILLUSTRATIONS

THE McFADDEN RESEARCHES

P. Blariston's Son \& Co., Pritishers, 1012 Wailut st., Inilatatifila.

\section{$\frac{514732}{1.12 .50}$}

\footnotetext{
LONDON

JOHN MURRAY, ALBEMARLE STREET, W.

September ig̨i
} 
All Rights Reserved

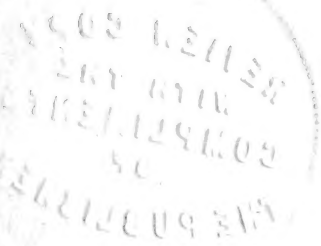




\section{PREFACE}

THE following papers outline a continuation of the results of the researches which were published by me eight months ago in a book entitled Induced Cell-Reproduction and Cancer. ${ }^{1}$

The book described a method by which it was found that human white blood-corpuscles and other cells can be made to divide when they are absorbing certain chemical agents from a film of jelly set on a microscope slide. The chemical agents evidently cause the divisions; and this fact formed the basis of a theory as to the possible causation of benign and malignant growths within the body, and led to the elaboration of experiments to try to prove the theory in question.

I was fully aware when I wrote it that the book was compiled in rather an unusual manner, and that the results which it mentioned were revolutionary to the older ideas; but it described a new method of research which has undoubtedly revealed new facts; and I considered that the way in which it was written might render the details of the complex experimental methods more readable, and facilitate their consideration-which I think it has done. Unfortunately, a group of gentlemen, whom I had thanked in the preface

1 London, John Murray, 1910. 
for assistance and all of whom with one exception formed a committee to associate me officially with one of the hospitals in Liverpool, apparently became alarmed, and, before any one had had time to study the work fully, wrote a letter to the medical journals disclaiming all responsibility for my statements. The disclaimer was unfortunately worded, because, since those who signed it omitted to mention that most of them formed my committee, it seemed to imply that I had deliberately exploited their names without any authority or without knowing them-which, of course, was not correct. Those who signed the letter are gentlemen eminent in Science, and it has therefore had a most detrimental effect on the trial of the new method by others, and on the consideration of the researches by those who have not yet seen the actual experiments themselves. In the United States especially, a country which I have recently visited and where I was privileged to describe and demonstrate some of the experiments at the most important Research Institutes at Philadelphia, New York, Buffalo, and Chicago, and where every facility was afforded to me to explain the methods, while I was received most cordially, yet I found at the outset a tendency to scepticism in many cases attributable to the disclaimer; in fact, some of the medical journals went so far as to refer to the words of my committee and then to condemn our work.

It seems that anything written about the cancer problem is inclined to excite suspicion. Apart from the extremely complex nature of the scientific problem itself, a worker in it is beset 
with the difficulty that people think he is trying to produce another speculation in the hope that it may ultimately turn out to be correct, or that he may increase his practice. As a matter of fact, we believe that the cancer problem is only a detail in the solution of the problem of the cause and control of cell-reproduction-or rather of the phenomenon of the reproduction of living matter. The person who solves this problem will, I think, have a far greater field in front of him than the mere practice of a "cure for cancer." Besides, we none of us practise.

This suspicion, coupled I think with the disclaimer, has led to the publication of our work in its present form. When our experiments merely dealt with problems concerning wellknown cell phenomena we met with no difficulty in getting the results published in scientific and medical journals; but now editors of scientific journals appear to be less inclined to insert our papers. After careful consideration, therefore, I think that it will be better to continue, as I have always meant to continue, to take all the responsibility, and to print the work independently for ourselves. We must publish our experiments, because others may be-in fact, we know that they are-working on similar lines; and nothing is gained by clashing in research.

Judging by the published reviews and the criticisms which I have received both in England and America, the question to be answered is whether my interpretation of the facts seen by the new method of in-vitro staining is correct or not; the main point turns on whether the 
figures which were described are really those of cell-division or are merely some accidental distortion. It is difficult to discuss the pros and cons of this point, because it is one about which we are absolutely certain. Any one who has seen the number of figures in all their phases which we have seen cannot possibly dispute them; and several persons have agreed that they are celldivision. ${ }^{1}$ Unfortunately, as I have said before, one cannot always induce the division-figures to order in such a manner that they resemble the well-known aspects pictured so frequently in text-books. There are many factors to be taken into consideration, such as the temperature, the consistency of the jellies, the vitality of the cells, the alkalinity, the degree of putrescence of extracts, and lastly the attitude which the cells may happen to present to the observer, over which we have no control whatever. Owing to scepticism people will only come with reluctance to see the experiments, and when they do arrive they frequently expect us to command living cells to undergo typically on every occasion the most complex physiological function of reproduction in the few moments which the visitors can spare us. In work of this nature it is necessary to spend many hours of careful observation, making control experiments and searching through many films. A cursory examination often leads to disappointment. If a fairly typical specimen happens to appear before the objective, however, many people become convinced, although their ardour is sometimes damped when they realise that the

I See letter in The British Medical Journal of January 11th, 1911. 
chromosomes of lymphocytes are formed from the Altmann's granules in the cytoplasm. This was specially the case in one of the cities in the United States, where I happened to obtain some good specimens. When first the figures were seen, the observers seemed unanimous about the celldivision; but after I had again shown them a resting cell for comparison and explained the figures, minutely pointing out the revolutionary fact about the chromosomes, our critics were not quite so unanimous. This is to be expected, and until the fallacies of "fixed" specimens and of the examination of unstained living cells are appreciated, we cannot hope to have our work established. Without exception, however, all observers seemed to be agreed that a new field for research has been opened and that the figures in the cells are unique.

Several reviewers have suggested that the division-figures are "artefacts" or are results of degeneration. Pathologists seem to be prone to label new phenomena with these expressions, but personally I think that no one can criticise researches of this nature without seeing the experiments themselves. Our answer to these allegations is that the cells always undergo a definite process before they divide; a series of figures is formed identical in every case; the chromatin is collected together, splits usually into a definite number of rods or pear-shaped bodies, some of which travel to one pole of the cell and some to the other; and, lastly, where there was one cell there are now two. We shall be most happy, however, to show the experiments to any one interested, 
It is important to note that Dr. Fantham, using our methods, has succeeded not only in inducing the division of Entamoeba coli, but also in causing this parasite to multiply through five generations without transplantation entirely by the action of "auxetics." 1 This is strong confirmatory evidence of our work.

As the line of experimentation which we are employing differs from those adopted by other workers in cancer research, as shown by recently published Reports, ${ }^{2}$ it may be valuable to explain this difference, and to summarise briefly the main principles underlying the solution of the problem. It has already been pointed out that cancer consists essentially of a growth composed of cells which are reproducing themselves too rapidly. In the malignant tissue the balance between cellreproduction and cell-death is not maintained, the proliferation being excessive. In order to find the cause of the disease, therefore, researches must be directed towards finding the exciting cause of this excessive cell-reproduction. Unfortunately, the immediate cause of normalapart from excessive or abnormal-cell-division has hitherto not been known, and hence, before one can attack the cancer problem, it would appear that the exact cause of normal cell proliferation must also be elucidated.

${ }^{1}$ See a paper by H. B. Fantham, D.Sc. London, in The Annals of Tropical Medicine and Parasitology, Vol. V., No. 1, April 1911.

2 The most recent Report is that of the Imperial Cancer Research Fund, issued on July 20, 1911, which describes the present position of the researches being conducted by that Fund. A new Italian journal, Tumori, August 1911, edited by G. Fichera and published in Rome, gives an excellent epitome of recent work done on the subject, 
In the first place, it may be said that there are two main theories regarding the cause of cancer, both of which appear to involve the idea that normal cell-division is an inherent vital function of the cell. All living matter is capable of reproducing itself, a fact which is so obvious that it appears to be taken for granted that reproduction is an intrinsic function of living matter, similar, for instance, to that of the assimilation of water or the power of movement; in other words, that there is no actual exciting cause which normally makes a living cell reproduce itself, but that the living protoplasm will continue to multiply automatically, so to speak, so long as it is alive.

With regard to malignant proliferation, however, one of the theories suggests that cancer is due to a perversion of this normal function owing to some unknown change occurring in the intrinsic characteristics of the cell itself; the cell no longer reproduces itself in a normal manner, but suddenly becomes excessively prolific, and produces offspring which also multiply very rapidly, exhibiting the well-known appearances of "cancer cells." The other theory leads one to believe that the abnormal cell-division is caused by the presence in the neighbourhood of the cells of a living parasite introduced into the body from without. It appears that many investigators of the first theory consider it inadvisable to make a frontal attack, because they do not hope to solve the nature of a vital function of protoplasm, but are trying to find out what will influence the growth of masses of cells or 
tumours by transplanting them through various animals under different conditions, especially with a view to the discovery of what will prevent their growth. Work based on the second theory has for its object the endeavour to isolate the parasite, to produce experimentally a malignant growth with it, and then to find some method of preventing and curing its action.

Apart from many speculations, in addition to these two main theories, there are, of course, several others; notably one suggesting that the parasite is an ultramicroscopic one, another that it is intracellular, and, lastly, there are those which indicate that cancer cells are normal ones which have reverted to the "reproductive" type, or, again, are inclusions of undeveloped or fotal tissues. Few of the theories, however, seem to attack the problem of the cause of normal and malignant cell-division directly. The explanation of how a parasite, even if it be ultramicroscopic or intracellular, can cause a living animal cell to reproduce itself too rapidly is not forthcoming. On the other hand, it has been suggested that cell-division is due to a combination of physical and chemical factors which so far have not been specified; and, again, there is the theory that all cells have the function of reproducing themselves automatically unless they are restrained by a chemical "anti" substance, although how the latter acts is not yet explained.

The line of work which we have adopted differs from the above in that we believe that normal cell-reproduction is not merely an intrinsic vital function or duty on the part of the cell, but is 
directly caused by chemical agents; we consider that before a cell can divide it must absorb a definite quantity of specific chemical substances. As already mentioned, we arrived at this conclusion because we found that certain human cells, which hitherto had never been seen to divide, could be made to undergo division figures on a microscope slide in response to chemical agents; a discovery which will be found fully described, together with the methods employed, in the book above referred to. In one of the following papers the chemical agents are specified and further investigated; and judging by the way in which these substances are set free in the body, we maintain that the death of cells, as caused by injury, for instance, gives rise to the reproduction of their living neighbours, for the exciting agents are set free by the death of protoplasm. If this is correct, we have also evidence to show that malignant proliferation may be brought about by the addition to the normal agents of other exciting substances, the combination of which causes abnormal or excessive cellmultiplication, and which can be produced in an injured site by the action of organisms. As already mentioned, our work has reached the stage at which it must be determined whether the figures which we can induce in the cells, and which we interpret as division figures, are really the phenomena of cell-division or not; an interpretation which involves a point revolutionary to commonly accepted cytological teaching.

I do not wish to imply that we originated the idea that cell-reproduction is affected by chemical 
agents, because certain substances were described as influencing the development of the eggs of certain fishes long before we induced human cell-division. But the work with human cells and the isolation of the actual chemicals is new, as well as the deduction from this work that normal cell-division is brought about by celldeath.

Provided our interpretations are correct, we have the field of research and methods for trying to find substances which will inhibit the action of the normal and of the "augmenting" agents which excite physiological and malignant division of individual cells. Moreover, we hope to be able to isolate the organisms whieh produce the augmenting substances, and to try to deal with them.

The experiments to be described were carried out in a laboratory of the Liverpool School of Tropical Medicine

The illustrations were kindly painted for us from the specimens by Miss E. H. Barry.

H. C. Ross.

26, Clarges Street, W. 


\section{CONTENTS}

Preface • . . . . . . . . 5

I

A Funther Investigation of the Chemical Substances which Cause the Cell-Division of Human LYMPHOCYTES • • • . . .

A Method of Making Permanent Fixed Films of Human Lymphocytes in which Division Figures or other Phenomena have been Induced by

Chemical Agents with the "Jelly Method". 34

\section{III}

A Method by which Cell-Division can be Induced in Human Lymphocytes in VItro while the Cells are Floating in a Solution which Contains the Necessary Chemical Agents • 39

IV

The Gasworks Prtch Industries and Cancer . . 42

The Action of "Auxetics" on Erythrocy'tes . . 48 



\section{LIST OF ILLUSTRATIONS}

\section{ALL PAINTED FROM FIXED FILMS}

FACING PAOE

I. "Control" Specimen. A "Restine" Lymphocyte . . 38

II. A Division Figure in a Lymphocyte. Profile Aspect - 38

III. A Division Figure in a Lymphocyte. Polar Aspect , 38

IV. A Division Figure in a Lymphocyte. Profile Aspect a 38

V. A Division Figure in a Lymphocyte. Polar Aspect . 38 


\title{
Further Researches into Induced Cell-Reproduction and Cancer
}

\author{
I
}

\begin{abstract}
A FURTHER INVESTIGATION OF THE CHEMICAL SUBSTANCES WHICH CAUSE THE CELL-DIVISION OF HUMAN LYMPHOCYTES
\end{abstract}

By H. C. Ross and J. W. Cropper

Is a former publication $(1)^{1}$ it has been shown that cell-division can be induced in human lymphocytes, polymorphonuclear leucocytes, and certain epithelial cells by means of chemical agents which have been called auxetics (excitors of reproduction). It has also been shown that certain other substances, notably alkaloids, excite amœboid movements in white blood-corpuscles; and these substances have been called kinetics. Thirdly, if a mixture of certain kinetics and auxetics is absorbed by the cells, the kinetic, while having no auxetic action of its own, greatly increases (augments) the action of the auxetic in inducing cell-division.

1 These numbers refer to former publications, which are listed at the end of the last paper. 
The substances which have the auxetic action can be divided in the first instance into two main groups-natural and artificial. For convenience we may use the former term as referring to substances which are found in the living body, or which are set free in a tissue when that tissue is damaged. The latter term refers to entirely artificial substances not found in the body, but which in most instances are manufactured synthetically. The same terms can be employed for the kinetics, although up to the present no kinetic substance has been discovered which, so far as we can find out, is produced physiologically in the body; the natural kinetics seem only to occur in pathological conditions. Up to the time of writing the former publication the known auxetics and kinetics were:

\section{Auxetics}

Natural : extracts of dead tissues, creatine, xanthine, "globin." 1 Artificial : certain aniline dyes.

\section{Kinetics}

Natural: choline, cadaverine, neurine.

Artificial : certain alkaloids, especially atropine.

In the present paper we propose to describe further researches in this subject, to enumerate other substances both natural and artificial which have been found to be auxetics or kinetics, to attempt to find out the active principle from each group of them, and lastly, to discuss the bearing of the knowledge gained on the problem of human cell-proliferation.

In the former publication it was shown that

1 The filtrate of a solution of hæmoglobin decomposed by heat. 
those substances which induced mitosis ${ }^{1}$ in lymphocytes could also be made to cause the division of polymorphonuclear leucocytes and those epithelial cells which were experimented on, but in the present researches we have confined our attentions entirely to the lymphocytes contained in human blood from the peripheral circulation. The reason for this is that, as already pointed out (1), it is much easier to induce lymphocytes to divide (under the experimental conditions) than the other cells, owing to the fact that they are less fragile and seem to have a higher vitality. At the same time it may be mentioned that, during the experimentation with the different substances to be enumerated, divisions have also been occasionally induced in polymorphonuclear leucocytes. Moreover, as already noted, the only substances with which mitosis has been induced in epithelial cells are those which also have the auxetic action on lymphocytes and leucocytes.

In these researches the technique employed has been the in-vitro method described in former papers; that is to say, the cells are spread on the surface of a film of agar jelly set on a slide and examined microscopically. The jelly contains

1 The application of the term mitotic to these induced figures has been questioned, because it has been suggested that, since there is no newly formed spindle and since the cytoplasmic granules form the chromosomes, the divisions should be considered to be of the amitotic variety. But we wish to maintain our original contention, for, though many atypical figures occur, divisions have been induced in lymphocytes in which the cells have gone through the phases similar to those of karyokinesis, and, with experience, it will be seen that the so-called atypical figures are in reality phases of the same phenomenon, except that the cells are distorted. The nucleus forms the spindle, however, and the granules form the chromosomes. 
the chemical agents, which, on being absorbed by the cells, cause them to divide, or to become excited, or to remain unaffected as the case may be, according to the nature of the substance. In the former publication experiments were described which demonstrated the fact that the substances which caused division of the cells in vitro on the jelly film also caused the proliferation of healing in vivo when directly applied to ulcers. In the present paper, however, we shall only describe the results obtained with the new substances in vitro with the jelly method; the in-vivo experimentation which must necessarily follow will be described on a future occasion.

The method has been fully described $(1,2)$, and need not here be repeated in detail. It will suffice to say that the jelly basis from which the films on the slides are made is known as "coefficient jelly," and contains the necessary salts to keep the cells alive; it is prepared in such a manner that other substances (e.g. auxetics or kinetics) from stock solutions can be added to it up to a total of 10 c.c.; and when a certain quantity of alkali (sodium bicarbonate) has also been added the substance or substances to be tested on the cells are absorbed by them, and the result watched.

In order to induce divisions (auxetic action) it is necessary to keep the slides at blood heat; and every slide is examined after ten minutes, because it may be taken as a general rule that, owing to the loss of vitality, unless the cells are in the act of division at the end of ten minutes, they will never divide under the experimental 
conditions. These conditions have been designated "the experimental ten minutes," and they also will be found explained in detail in former publications.

In order to test for excitation of amœboid movements (kinetic action) the same rule applies, with the exception that the slides are kept at the room temperature, because white blood-cells seem to show more exaggerated amoboid movements in response to kinetics at a lower temperature than they do at blood heat.

When testing a substance to see if it has kinetic action several specimens were made from the jelly which contained the substance, and control specimens were made simultaneously which contained no such substance, but only the usual salts; the two slides being kept together. Unless more than 50 per cent. of the white cells in the test specimens showed marked exaggerated movements with extrusion and retraction of long pseudopodia in definite contrast to the control specimens, the substance was considered not to be effective. In a similar way, when testing for auxetic action, unless a large number of lymphocytes showed well-marked division figures at the end of the ten minutes, the substance in the jelly was considered not to be effective. With experience these figures can easily be recognised, even if no stain is employed and the cells are colourless. The cells adopt an appearance quite unlike resting cells (a fact which a control specimen will readily demonstrate), and in many instances the arrangement of the chromosomes (frequently contained in finger-like processes of cytoplasm), or even 
their number, can be clearly seen. In fact, a lymphocyte in the act of division cannot be mistaken after a few have been recognised.

Auxetics.-In the first instance aniline dyes were tried, and the following were found to be capable of inducing the divisions.

\section{Artificial : azur II}

$(0.5 \text { c.c., } 1 \text { per cent })^{1}$

"

polychrome methylene blue.

$"$ azur I

$"$ methylene blue .

All these dyes stain the granules of the cells in vitro, and mitosis occurs at about the time when the granules are colouring. The continued diffusion of the dyes causes death.

Some more dyes were then tried, but none were capable of inducing divisions by themselves. They were therefore tried with atropine. It has already been stated that atropine sulphate is a powerful kinetic, and although it is not itself an auxetic, it greatly increases the action of the substances which induce cell-division. This augmentation, as it has been called, will increase the action of the auxetic as much as fivefold; that is to say, in order for a given substance to induce divisions by itself, it is necessary for the jelly to contain a certain quantity of it. If the jelly contains less than this quantity, it is not effective. Suppose now the jelly contains only one-fifth of the effective quantity, but also contains 0.7 c.c. of a 1-per-cent solution of atropine sulphate, the divisions will occur as before.

1 The numbers within parentheses refer to the strength of the stock solution of the substance and the amount of it required to be contained in the 10 c.c. of jelly. 
Hence we say that atropine augments the auxetic fivefold; and these augmented divisions are frequently of the asymmetrical variety.

Among those dyes which previously were not effective,

$$
\begin{aligned}
& \text { Artificial : neutral red } \quad . \quad \text {. }(0 \cdot 4 \text { c.c., } 1 \text { per cent }) \\
& \operatorname{eosin}^{1} \cdot \text {. }(1 \text { c.c. },)
\end{aligned}
$$

induced divisions in the presence of atropine; gentian violet and methyl violet, however, were not effective at all.

There appears to be no chemical principle common to all these dyes.

With regard to the natural auxetics, it has been shown that extract of suprarenal gland is a powerful excitor of cell-division by itself; and that if atropine is present, extracts of muscle, spleen, liver, testis, etc., are also auxetics. Creatine (4 c.c., 1 per cent), which is contained in some of these extracts, readily induces divisions by itself, and so will xanthine (1 c.c., 1 per cent) if its action is augmented by atropine. Up to the time of writing the former publication, however, we had not succeeded in obtaining the auxetic effect with creatinine.

At this stage we consulted Dr. Titherley, Lecturer in Organic Chemistry at the Liverpool University, in the hope of finding out whether there was any principle common to these substances. He suggested that creatinine should again be tried, pointing out the fact, of which we were unaware, that alkali in the hot converts creatinine into the sodium salt of creatine, thereby

${ }^{1}$ Eosin is a very feeble auxetic. It does not stain the living cells. 
neutralising the alkali in the jelly. In all these experiments 1 c.c. of a 1-per-cent solution of sodium bicarbonate is present in the 10 c.c. of jelly to ensure the correct diffusion of the substance into the cells, and, since no results can be obtained unless this diffusion is arranged for the "Coefficient of Diffusion" of the cells, it was realised that the neutralisation of the alkali by creatinine might have rendered fallacious our former experiments with that substance. Creatinine was therefore retried with four more units of alkali (1.4 c.c. in all), when it proved to be an auxetic by itself as powerful as creatine.

Dr. Titherley then suggested that there is a portion of the molecule, the amidine grouping $(\mathrm{N}-\mathrm{C}=\mathrm{N})$, common to creatine, creatinine, and xanthine, and he supplied us with a series of substances, some of which contained this grouping and others which did not. We tried them on the cells haphazardly, but we were not informed of the exact nature of the several substances until after the experiments were complete.

Out of the series, hippuric acid, ethylamine, ethylenediamine, diethylamine, and glycine ester were not effective, and they do not contain the amidine grouping. But-

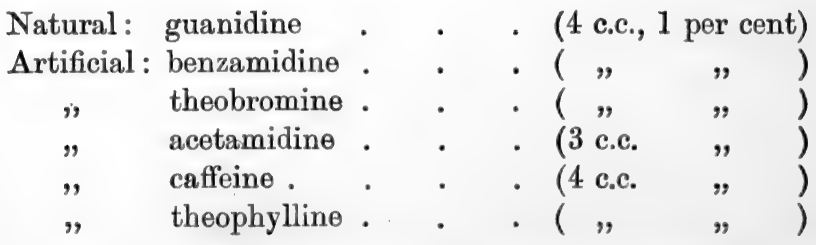

were all powerful excitors of cell-division like creatine and creatinine. And the striking point 
is that every one of them contains the amidine grouping in their molecules. Guanidine is one of the simplest amidines. Up to the present, therefore, every substance yet tried which contains the amidine grouping will cause the cell-division of human lymphocytes.

Those substances which were not effective before were then retried in the presence of atropine. Still, they were all ineffective with the exception of one-ethylamine.

Now ethylamine, like the aniline dyes, does not contain the amidine grouping in its molecule; and the fact that it is an auxetic if augmented by atropine led us to try other amines both with and without atropine. If atropine is present, the following primary aliphatic amines are auxetics :

$$
\begin{aligned}
& \text { Natural : methylamine . . }(0 \cdot 3 \text { c.c., } 1 \text { per cent }) \\
& \text { Artificial : ethylamine . . . }(0 \cdot 2 \text { c.c. } ",) \\
& " \text { propylamine . . }(0.5 \text { c.c. } ") \\
& " \text { isobutylamine . . ( " " ) }
\end{aligned}
$$

but they are inert by themselves.

The secondary amines, dimethylamine, diethylamine, and diphenylamine (all artificial), were tested with and without atropine, but they have no action.

The following amino-acids all proved to be auxetics, provided their action is augmented by atropine :

$$
\begin{aligned}
& \text { Natural : glycocoll . . . (1 c.c., } 1 \text { per cent) } \\
& " \text { leucine . . . · ( " " }
\end{aligned}
$$

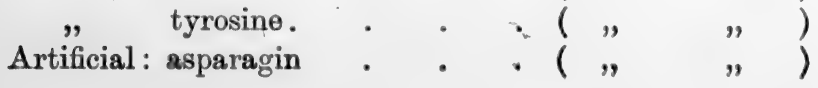




\section{EXCITORS OF CELL-DIVISION}

The next two substances are auxetics by themselves, viz. :

Artificial: tetra-ethyl ammonium hydroxide +. (3 c.c., 1 per cent)

" meta-phenylene diamine ( " , )

and,

Artificial : betain.

" tetra-methyl ammonium hydroxide . . ( $(0.3$ c.c. " )

are also auxetics if atropine is absorbed by the cells as well.

Kinetics.-At the time of writing the former publication, the known kinetics were:

\begin{tabular}{|c|c|c|c|c|c|}
\hline Artificial: & atropine & & & (0.7 c.c., & $\mathbf{r}$ \\
\hline tor & quinine & - & - & (1 c.c. & $"$ \\
\hline " & cocaine. & & & ( 2 c.c. & " \\
\hline " & pilocarpine & & & $(0.5$ c.c. & $"$ \\
\hline$"$ & strychnine & & & (1 c.c. & $"$ \\
\hline , & brucin $\theta$ & & & & , \\
\hline$"$ & codeine & • & & ( 0.3 c.c. & $n$ \\
\hline ", & morphine . & • & & $(0.2$ c.c. & , \\
\hline , & pyridine . & & & $(0.1$ c.c. & , \\
\hline & quinoline & & & (1 c.c. & , \\
\hline Natural $^{1}$ : & choline & • & & & $"$ \\
\hline " & cadaverine & & & ( , & $"$ \\
\hline$"$ & neurine & - & & $(0.5$ c.c. & $"$ \\
\hline
\end{tabular}

Others have since been tried, and the following are effective excitors of amœboid movements :

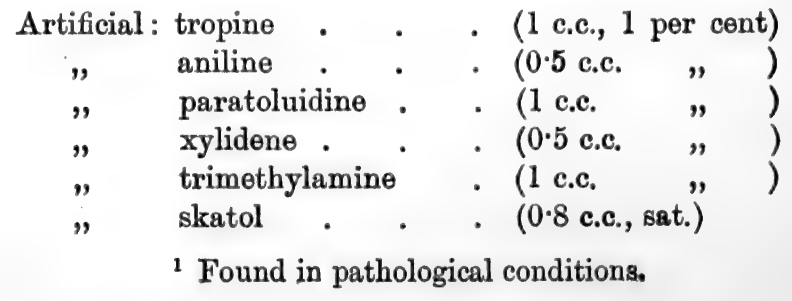


Dimethylamine, diethylamine, diphenylamine, ethylenediamine, isoquinoline, and alloxan have not this action.

It may here be mentioned that in no instance have we found an auxetic substance to be a kinetic as well, and, vice versa, no kinetic ever seems to be an auxetic. All the substances have been tested for both actions.

Augmentors.-It has been pointed out that certain of the kinetic alkaloids enumerated above, especially atropine, greatly augment the action of the auxetic in inducing cell-division. Some of the other kinetics were now tested to see if they also had this augmenting action. The jellies contained some powerful auxetic, such as suprarenal extract, guanidine, or theobromine, but in insufficient quantities for these substances to induce divisions by themselves in the experimental ten minutes. A certain amount of the kinetic was then added to the jelly and films made, the specimens being controlled by films from jellies which did not contain any augmentor.

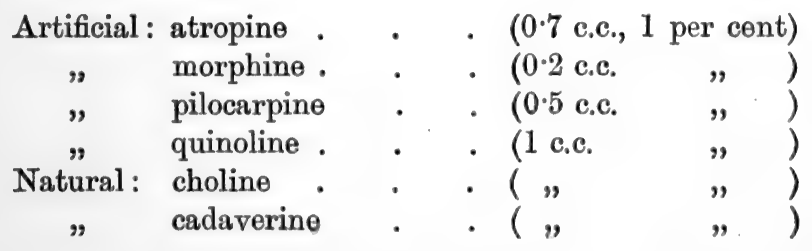

From the foregoing experiments it will be seen that, while those substances which are auxetics by themselves directly cause cell-division, there seems to be no specific chemical grouping contained in them which can produce this action. 
All the agents which contain the amidine grouping are effective, and we think therefore that it may be said that the amidine grouping is a cause of cell-division. But, in addition, there are many substances which do not contain the amidine grouping and yet induce mitosis. The primary amines cause division provided their action is augmented by choline, cadaverine, or atropine; and the same may be said of the amino-acids. Yet there is a wide difference between the composition of the molecules of all these groups. There seems to be a large variety of substances which cause the division of lymphocytes in vitro; but if the natural ones are picked out of the list, it will be found that they are entirely confined to those agents which belong to the three groups-amidines, primary amines, and aminoacids. With regard to the two latter, we must add the qualification that they are not effective under the experimental conditions unless their action is augmented by choline or cadaverine (atropine, being artificial, may be neglected).

This augmenting action appears only to be brought about by substances which are kinetics. At one time we thought that the augmentation was due to the fact that the cells, being under the stress of excitation (as demonstrated by the exaggerated amœboid movements), in response to the kinetics, became pathologically very prolific if they also absorbed an auxetic. But there are several powerful kinetics, e.g. skatol, aniline, trimethylamine, which are not augmentors; a fact which disproves this theory.

Like the auxetics, there is no part of their 
molecules common to all the kinetics which could be held responsible for their action, either as excitors of amœboid movements or as augmentors. They seem to belong to certain groups (e.g. alkaloids, primary aromatic amines), but the constitution of their molecules differs widely.

Hence we cannot form any definite opinion as to how the auxetic immediately causes celldivision, or the kinetic excitation or augmentation. It is evidently some chemical process which goes on between the substances concerned and the living cell protoplasm. We think that until more is known about the constitution of the latter it is useless to suggest any theory.

With regard to the action of the aniline dyes, however, it may be pointed out that these dyes cause gradual (presumably molecular) death of the cells, because the granules can be seen to stain one by one while the cell is alive; but so soon as the nucleolus is reached by the stain, cell death occurs. The natural auxetics containing the amidine grouping are set free by the death of protoplasm, and it is possible that the aniline dyes, by causing gradual molecular death of part of the cell protoplasm, may be the indirect means of setting free the auxetics from that protoplasm, which in their turn induce the cell to divide. This is a speculation which we think one is justified in suggesting, because there appears to be no experimental method by which it can possibly be elucidated.

Lymphocytes are induced to divide, then, by substances containing the amidine grouping, which are set free in any part of the body where 
an injury has occurred. As has already been shown by experiment, these substances cause the proliferation of lymphocytes, leucocytes, and certain epithelial cells; in fact, we know by in-vivo experiments that they can cause the cell-proliferation of healing. If the wound or damaged site becomes infected, after a time the proteins produced by the autolysis are further split up, and the primary amines and amino-acids are produced. These agents may cause slight proliferation, although they are not effective by themselves on a microscope slide unless augmented. Still, the exuberant granulations usually seen in an infected wound may be caused by these additional auxetics produced by the decomposition of infection. ${ }^{1}$ If the infected wound becomes a very chronic one, cadaverine and choline may also be produced. When this happens, judging by the in-vitro experimentation, a great change must occur. The action of the normal auxetics, xanthine, etc., becomes greatly augmented. The additional auxetics, methylamine, propylamine, glycocoll, leucine, and tyrosine, even if not active before, now become converted into powerful excitors of cell-division; and from the fact that cadaverine and choline excite amœboid movements, the proliferating cells may also be caused to infiltrate.

In conclusion it should be mentioned that it has not been possible to test all strengths of the several substances experimented with. Hence,

' It has already been shown (1) that while extracts of dead tissues induce cell-division, their action is greatly increased if putrefaction has set in. 
when we have stated that some of them are not effective, it must be understood that we mean that they are not effective in the strengths tried. It is manifestly impossible to try every concentration. We have, however, employed several strengths of each substance, beginning usually with 1 c.c. of a 1-per-cent solution, and then halving, quartering, doubling, and quadrupling the amount.

We wish to acknowledge our indebtedness to Dr. Titherley for his advice. 
A METHOD OF MAKING PERMANENT FIXED FILMS OF HUMAN LYMPHOCYTES IN WHICH DIVISION FIGURES OR OTHER PHENOMENA HAVE BEEN INDUCED BY CHEMICAL AGENTS WITH THE "JELLY METHOD"

By J. W. Cropper and H. C. Ross

(By H. C. Ross)

W Ітн the jelly method of in-vitro staining (1), the films could not hitherto be kept, because the cells soon died and then became disorganised and disappeared. All attempts to fix the cells in the act of division or of extruding pseudopodia failed, and we had to resort to photomicrography to record the specimens-a procedure which was elaborate and unsatisfactory, and, of course, gave pictures not comparable with those presented by the cells themselves. The chief difficulty in fixing the films lay in the fact that one could not remove the cover-glass without disarranging the cells and distorting them. When they are resting between the jelly and the cover-glass they become admirably arranged side by side while they absorb the substance from the jelly, but if the cover-glass is even touched, the living and floating cells all run 
together and the specimen is spoilt. In order to overcome this difficulty, I asked Dr. Cropper to make some experiments to try to obtain fixed films, which he has been able to do by the following process. We are now in possession of a few films of lymphocytes from the peripheral circulation, killed and fixed in the act of cell-division induced by chemical agents (auxetics), and this has enabled us to discard photography as our means of recording the phenomena.

\section{(By J. W. Cropper)}

By the following process one can fix and stain any specimen of cells examined by the in-vitro " jelly method." It is immaterial what chemicals the jelly may contain; and it does not matter whether the chemicals are causing excitation of amœboid movements (kinetics) or are inducing cell-division (auxetics), for description of which former publications may be referred to.

By way of example, in the present note I shall describe the preparation and subsequent fixation and staining of the film in which cell-division is induced in lymphocytes.

Preparation of the Jelly Film.-As already published, creatine, creatinine, guanidine, theobromine, benzamidine, and other substances containing the amidine grouping $(\mathrm{N}-\mathrm{C}=\mathrm{N})$ induce mitotic figures in lymphocytes, and their action is greatly increased by atropine, choline, and cadaverine. We may use a mixture of theobromine and atropine.

To a tube containing 5 c.c. of "coefficient 
jelly" (1) add 1 c.c. of a 1-per-cent solution of theobromine, ${ }^{1} 0.7$ c.c. of a 1-per-cent solution of atropine sulphate, 1 c.c. of a 5 -per-cent solution of sodium bicarbonate, and $2 \cdot 3$ c.c. of distilled water-total, 10 c.c.

The tube is steeped in boiling water until the jelly melts and mixture is complete. The whole is then boiled and a drop of the molten mixture poured on to a microscope slide, where it is allowed to cool and set. A drop of citrated blood (1) is placed on to the centre of a coverglass, which is then inverted and allowed to fall -blood downwards-flat on to the convex surface of the jelly film on the slide. The blood spreads out evenly between the jelly and cover-glass, and the slide is placed in the $37^{\circ} \mathrm{C}$. incubator for ten minutes. It may then be examined with the microscope. The cells should be admirably spread out one by one ; the polymorphonuclear leucocytes should nearly all be burst; but the lymphocytesin spite of the fact that they are unstained-should nearly all be seen to be exhibiting some phase of mitosis. Because the jelly contains atropine many of the figures may be asymmetrical.

Fixation.-In the bottom of a watch-glass place a few drops of a saturated solution of osmic acid. The slide should be inverted and allowed to rest on the edges of the watch-glass with the jelly film and cover-glass downwards, so that the fumes of the osmic acid impinge directly on the coverglass. None of the osmic-acid solution should

${ }^{1}$ Theobromine is not quite soluble to 1 per cent, but the solution should be shaken up and then added. It will dissolve in the jelly into which it is mixed. 
itself touch the film or cover-glass. The coverglass will not fall off the jelly, nor the jelly fall off the slide, but the fumes will slowly pass in between the cover-glass and jelly, fixing the cells in their progress. The whole preparation may be covered with the lid of a cardboard box and allowed to remain for three-quarters of an hour.'

Removing the Cover-glass without Disturbing the Cells. - The slide is removed from the watch-glass and laid on the table, film and cover-glass uppermost. A few drops of ethyl chloride (such as is used to produce anæsthesia by freezing) are flooded on to the cover-glass, and then by breathing on to the slide for a few moments the cover-glass suddenly becomes encrusted with ice. When this happens the jelly film on which the cover-glass is resting contracts away from the edges of the latter. With a pair of sharp-pointed forceps the cover-glass is quickly seized and lifted bodily off the jelly film with most of the cells fixed and frozen on to it in situ. It may then be laid on the bench, cells uppermost, until dry.

Staining and Mounting.-The cover-glass is placed in lion-forceps and the cells stained by Jenner's, Giemsa's, or other dyes as convenient. I have found Jenner's stain to be very suitable. After staining it may be mounted in Canada Balsam, and the film can be kept as a permanent specimen.

If the cover-glass is held up to the light it will be seen that a ring is formed near its centre. This is the limit of fixed cells; they are

1 Formalin vapour can be used instead of osmic acid, but it has not the same penetrating power, and the results are not so satisfactory. 
only fixed at the periphery - the ring being the line up to which the osmic acid has succeeded in penetrating. The outer portions of the coverglass, therefore, should be the part examined, when it will be found that the cells are nicely spread out and that many of the lymphocytes show some aspect of division figures. (See illustrations.)

Of course, by no means all the white cells adhere to the cover-glass, many being left on the jelly film; and therefore several fixed films have to be made before many dividing cells can be found. In any case, in our opinion, the pictures presented by these fixed preparations do not equal the staining of the living cells as previously described (1). 


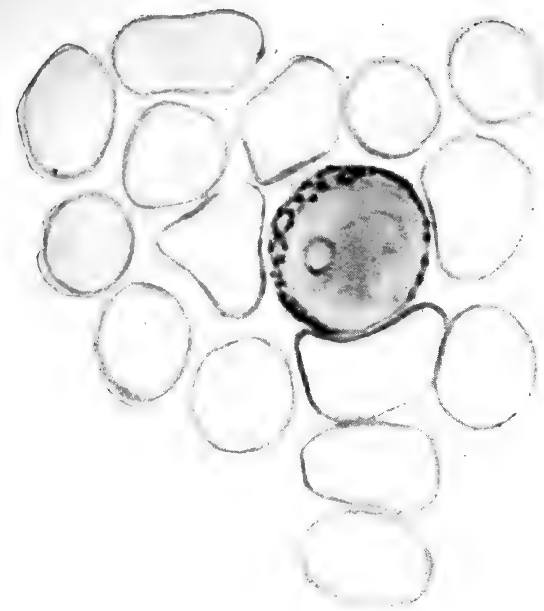

I.

From a fixed film.

"Control specimen." A "resting" lymphocyte. The "specimen" from which this field was painted was prepared in identically the same way as the subsequent specimens, fields of which are depicted in the following plates, except that the jelly film contained no auxetic. Jenner's stain. 


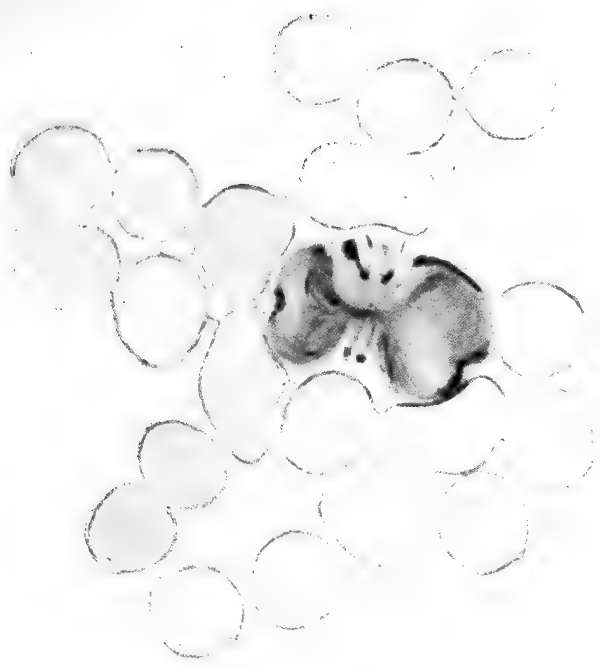

II.

From a fixed fllm.

A division figure in a lymphocyte. Profile aspect. Induced by theobromine. 
-

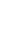




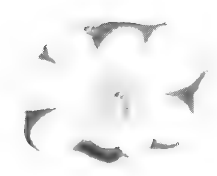

III.

From a fixed rilm.

A division figure in a lymphocyte. Polar aspect. Induced by theobromine. 

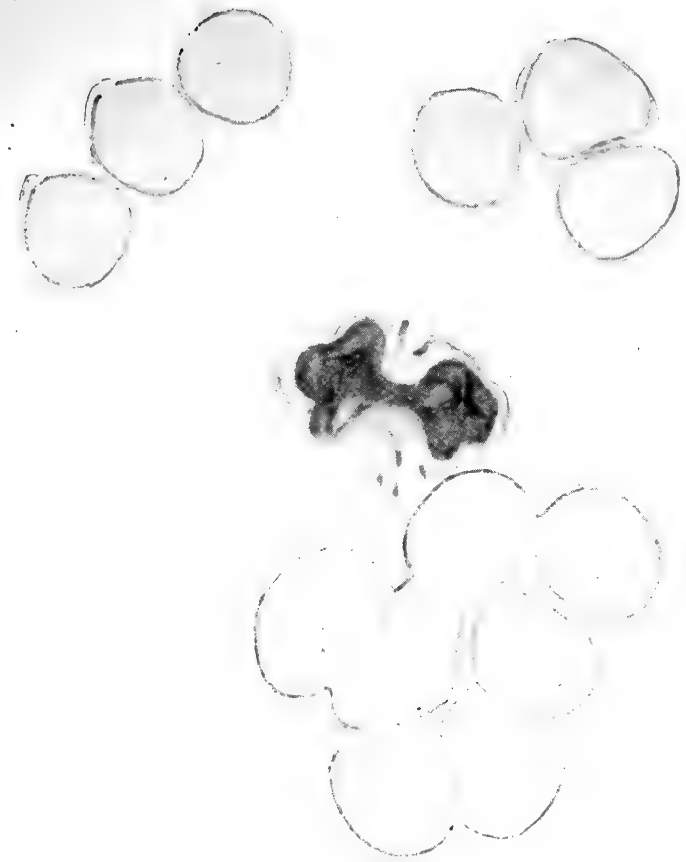

IV.

From a fixed film.

A division figure in a lymphocyte. Profile aspect. Induced by theobromine. 



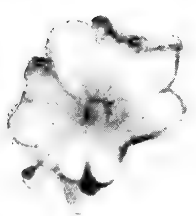

V.

From a fixed fim.

A division figure in a lymphocyte. Polar aspect.

Induced by guanidine. 



\section{III}

A METHOD BY WHICH CELL-DIVISION CAN BE INDUCED IN HUMAN LYMPHOCYTES IN VITRO WHILE THE CELLS ARE FLOATING IN A SOLUTION WHICH CONTAINS THE NECESSARY CHEMICAL AGENTS

By H. C. Ross

UP to the present, it has only been possible to induce divisions in individual white blood-corpuscles when the cells are spread out under a cover-glass on the surface of a jelly film set on a slide. The jelly must, of course, contain the proper amount of salts to keep the cells alive, and also an "auxetic" substance which is the immediate cause of the cell-division (1). By this method each cell is pressed into the jelly and has its own portion of jelly surface from which it absorbs the auxetic substance.

Hitherto, as the cells only appeared to divide in vitro under these conditions, it was thought that they probably had to be resting on a surface before they would undergo mitosis; but, as I shall describe in this note, it has been found that the cells can be made to divide while floating in a 
solution, provided that solution receives a supply of the necessary chemical auxetic.

A good auxetic jelly should be prepared, such as that described in the last paper, or a similar jelly containing acetamidine in the same strength as and instead of the theobromine will do equally well. Putrid suprarenal extract is also a very good excitor of cell-division.

The jelly is melted and a small quantity of it poured into a narrow test-tube, which is stood upright at the room temperature while the jelly sets at the bottom of the tube. The upper surface of the set jelly, of course, is concave.

In a capillary tube, a volume of a solution containing 3-per-cent sodium citrate and 1-percent sodium chloride is mixed with an equal volume of blood drawn from the finger. Two small drops of this mixture are carefully allowed to fall on to the cup-shaped surface of the jelly in the tube. A plug of wet cotton-wool is placed within the mouth of the tube to saturate the air in it in order to prevent evaporation, and the tube is corked up. Lastly, the tube is placed upright in the $37^{\circ} \mathrm{C}$. incubator for three-quarters of an hour.

On removal from the incubator, it will be seen that the corpuscles have sunk towards the bottom of the citrated plasma in the cup-shaped surface of the jelly. By gently shaking the tube, the corpuscles and fluid are again mixed up. With a narrow pipette, this mixture can be removed, and if a drop of it is examined microscopically between a cover-glass and a slide, many of the lymphocytes will be seen to be floating about undergoing the act of mitosis, The auxetic substance diffuses from 
the jelly into the citrated plasma, and the cells are able slowly to absorb the substance as it passes into the solution.

Ordinary fixed films can now be made from the rest of the mixture in the pipette. Films made in this way, however, have not proved to be very satisfactory because the dividing cells are frequently ruptured or distorted out of recognition. It may be pointed out that in making an ordinary blood film by placing a drop of fresh blood on a slide and spreading it out with the edge of another slide, the lymphocytes, being in the resting stage and spherical in shape, will always appear as circular cells composed of nucleus, granules, and cytoplasm, no matter in what attitude they happen to come to rest. But when the cells are elliptical, figure-of-eight, or spindle-shaped, as they are when they are dividing, the process of spreading them out by force on the surface of the slide frequently distorts them or even tears them asunder. The delicate mitotic figures therefore may not be discernible, or the cells may be seen to lie in fragments in different parts of the slide. We have found it preferable to place a drop of the mixture containing the dividing cells on to a cover-glass and then to invert the latter on to a film (set on a slide) of agar jelly containing 1.5 per cent of sodium citrate and 1 per cent of sodium chloride. This causes the cells to come to rest gradually and evenly spread out without distortion; and they can afterwards be fixed and stained by the procedure described in the last paper. 


\title{
IV
}

\section{THE GASWORKS PITCH INDUSTRIES AND CANCER $^{1}$}

\author{
By H. C. Ross and J. W. Cropper
}

Soov after the publication of Induced CellReproduction and Cancer, we received a letter referring to the incidence of cancer amongst the workmen employed in the manufacture of fuel "briquettes." The letter informed us of the proposed Home Office Regulations to prevent this incidence; that the Regulations only applied to workers with pitch made from gasworks tar, and not from blast-furnace tar ; and asked if we could indicate which ingredient caused the cancer, as it could no doubt be eliminated during the distillation of the tar.

As this letter was the first information which we had that the high incidence of cancer was caused only by the gasworks pitch and not by the blast-furnace pitch, and as this point is obviously of great importance to cancer research, we communicated with the Home Office. Dr. (now Sir Arthur) Whitelegge, the Chief Inspector of Factories, kindly gave us full information, and

${ }^{1}$ Abridged from an article by us in The British Medical Journal, April 15, 1911. 


\section{THE DANGER OF GASWORKS PITCH 43}

sent us Dr. Legge's original reports on the subject. It seems that while cases of warts and swarthy skins are very common, and epithelioma fairly frequent, among the workers with gasworks-tar pitch, Dr. Legge could not find these conditions among the comparatively small numbers of workers examined handling blast-furnace tar pitch. Hence in the proposed Home Office Regulations the following clause appears: "I hereby ... make the following Regulations, and direct that they shall apply to all factories and workshops in which the said manufacture is carried on, except factories or workshops in which no pitch other than blast-furnace pitch is used in the manuof "briquettes" (the italics are ours).

We have also made inquiries, and think that there appears to be strong evidence that the warts, epithelioma, etc., are caused only by the gasworks pitch. Blast-furnace pitch is made from tar which is distilled at a lower temperature. The pitches are powdered, mixed with small coals, and compressed into briquettes. The proposed Regulations, if enforced, will provide for the establishment of bathing accommodation and overalls to protect the men from pitch dust.

Reverting to the theory that cancer may be due to chemical auxetics and augmentors of celldivision, we undertook some experiments to see whether any such substances could be found in the tars and pitches. We procured samples of both. The method employed need not here be described in detail; but we may mention that in the case of the tars 10 c.c. of each was mixed with 90 c.c. of a 5-per-cent solution of $\mathrm{HCl}$, 
shaken up, filtered, and neutralised. In the case of the pitches, each form was finely powdered, and then 10 grams of it was mixed with 100 c.c. of the 5-per-cent solution of $\mathrm{HCl}$, filtered and neutralised. Certain quantities of the filtrates were added to " coefficient jelly," which also contained 1 c.c. of a 5-per-cent solution of sodium bicarbonate; the total was boiled and allowed to set as films on microscope slides. A drop of fresh citrated blood from the finger was then mounted on to each film, which was incubated for ten minutes at $37^{\circ} \mathrm{C}$., when the lymphocytes were examined. Briefly, the result may be tabulated thus :

\begin{tabular}{l|c|c}
\hline & $\begin{array}{c}\text { Contains Excitors of } \\
\text { Cell-Division } \\
\text { (Auxetics). }\end{array}$ & $\begin{array}{c}\text { Contains } \\
\text { Augmentors of } \\
\text { Cell-Division } \\
\text { (Kinetics). }\end{array}$ \\
\hline $\begin{array}{l}\text { Gasworks-tar } \\
\text { Gasworks-tar pitch } \\
\text { Blast-furnace tar }\end{array}$ & $\begin{array}{c}\text { Yes }(0.3 \text { c.c.) } \\
\text { Yes (1 c.c.) } \\
\text { Blast-furnace tar pitch }\end{array}$ & $\begin{array}{c}\text { Yes (1 c.c.) } \\
\text { Yes (1 c.c.) } \\
\text { (if augmented by atropine) } \\
\text { Yes (2 c.c.) } \\
\text { (if augmented by atropine) } \\
\text { Yes (1 c.c.) }\end{array}$ \\
\hline
\end{tabular}

Hence it appears 'that gasworks tar contains a powerful excitor of cell-division, and also an augmenting substance (kinetic). The same can be said of gasworks-tar pitch. Blast-furnace tar, and pitch made therewith, however, while containing a weak substance which will induce divisions if its action is increased by atropine,

1 These numbers refer to the quantities of the filtrates to be added to the jelly. 
do not contain any augmenting kinetics which, from previous work, appear to be the cause of pathological (unsymmetrical) cell-division. We submit, therefore, that this is strong evidence that the chemical agents which cause augmented cell-division of lymphocytes under the microscope have something to do with the causation of cancer, because, in addition to other evidence already published, these agents appear to exist only in the one form of tar and pitch which causes the larger incidence of the disease in the industries where it is employed. The gasworks tar and pitch are among the most effective substances we have yet found for inducing mitotic figures in lymphocytes.

The experiments have been repeated with a 20-per-cent solution of ordinary soot, and both auxetics ( 1 c.c. with atropine) and kinetics $(0.2$ c.c. $)$ can be extracted from it, although it is not so effective as gasworks tar for inducing mitosis. Lastly, it may be mentioned that these auxetics can also be extracted by water instead of hydrochloric acid, but cannot be extracted by alkali. What their exact nature is we do not yet know.

The question now arises: Can these principles be eliminated from the tar without injuring the pitch; and, if so, will the pitch then no longer be dangerous to the workmen other than those who deal with it prior to such treatment? We have tried to answer the first question by experiment on a small scale in the laboratory by washing the pitch, and then again mixing it with water to see if more auxetics and kinetics can be ex- 
tracted. Extracts of washed pitch so treated no longer induced cell-division or excitation.

The question whether pitch from tar so treated is no longer dangerous can only be answered by the use of such pitch (provided it is still suitable for the manufacture of fuel) in briquette works for a period of several months, to see if the incidence of warts, ulceration, and epithelioma is reduced. Unfortunately, the Home Office Regulations, if imposed, would render fallacious such an experiment, because it would be impossible to ascertain whether any amelioration of the incidence of cancer-if such occurs-is due to the use of pitch made from the so-treated tar, or to the bathing accommodation and overalls supplied for the workmen. In our opinion the Regulations, which are based on the obvious principles of hygiene and cleanliness, are very necessary, but it might be of great value to cancer research if it could be definitely ascertained before the Regulations were imposed whether the dangerous principles can be effectively removed from the tar or pitch. An inquiry is to be held on the subject shortly, to consider some objections to the Regulations raised by the Patent Fuel Companies; and it is possible that this experimental corroborative evidence as to there being cell-division-inducing agents in the tar and pitch may be useful to the parties concerned.

Since the above was written we have heard that the inquiry stands adjourned for some time owing to strong objections raised against the Regulations. This will give us an opportunity to see if the 
dangerous principles can be eliminated from the tar from which the pitch is made. We have already tried washing the pitch, and one of the Patent Fuel Companies very kindly did this on a large scale-washing several tons-but unfortunately the process injured the "binding " quality of it. Hence it will be necessary to experiment with the tar. 


\section{V}

\section{THE ACTION OF “AUXETICS" ON ERYTHROCYTES}

By Edward Halford Ross

IT has been discovered by H. C. Ross that certain substances, which have been named by him auxetics, have the power to induce cell-division in lymphocytes, leucocytes, and certain other cells. The methods by which such divisions may be demonstrated have been fully described $(1,2)$. Stated shortly, they consist in placing the cells to be watched on a jelly under the microscope-the jelly containing the auxetics; the auxetics are caused to diffuse from the jelly into the cells by the action of heat and alkali solution in the presence of certain salts. Further research has shown that auxetics belong to chemical groupings, viz. amidines, amino-acids, and amines; and a number of them have been isolated. It has also been discovered that the extracts of dead tissues have the same action, probably on account of the creatine and "globin" present in them, for these substances are auxetics.

Following this discovery, an attempt was made to induce normal erythrocytes to divide by similar 
means; but no matter what strength of auxetics was used, healthy red blood-corpuscles refused to show any signs of division under the microscope. However, the jelly method of examination brought to light certain features in these cells which before were unknown.

A jelly containing the necessary substances was said to have a certain Index of Diffusion (3) according to the amount of those substances and its alkalinity and saline content. As the behaviour of the lymphocytes, leucocytes, and other cells varied according to that Index of Diffusion of the jelly on which they were resting, and was influenced by the degree of temperature and the length of exposure to it, these cells were said to possess certain Coefficients of Diffusion (3); for it was found that these cells will only divide when the necessary substances have diffused into them at a certain rate. But it was also noted that the same kind of cell, for example lymphocytes, possessed varying coefficients of diffusion when taken from persons suffering from certain diseases; thus lymphocytes taken from a case of cancer have a lower coefficient than normal cells, and the substances will diffuse into them more easily than into the cells of healthy persons.

But in any case, it is necessary to keep the cells for ten minutes at $37^{\circ} \mathrm{C}$. on a jelly which contains the auxetic substance and salts in suitable proportion; unless all these factors are present the cells will not divide. If blood-corpuscles are placed on a jelly containing no salts they are destroyed at once-the leucocytes burst, and the erythrocytes lake (4). A certain salt content, 
therefore, is necessary for the examination of blood by this method.

During this experimentation it was found convenient to add stain to the jelly in order that the minute structures of the component parts of the cells could be distinguished, and the part these structures play during cell-division noted; the stain diffuses into the cells with the auxetics. Then it was found that the stains used (the aniline dyes) would-if made sufficiently concentratedkill the cells, and that the staining of the centrosomes was coincident with death of the whole cell. But when used in weaker solutions the stain would diffuse into the cells causing staining only of the granules in the first place, the cell being able to continue its movements, until, after some time, the centrosome stained; the movements ceasing as death occurred. It was discovered that if the diffusion of the stain into the cells was sufficiently prolonged, the stain itself would also cause division to be induced, even without other auxetics. The stains commonly used were Unna's polychrome methylene blue and azur. The cell would divide as the granules within it stained; but as soon as the centrosome became stained the whole cell died, and the process of division ceased, the structures of the cell remaining in the posture of division reached when death occurred until the ultimate disintegration, or achromasia, set in and the cell contents liquefied and broke up. It was suggested that the dye caused molecular death in the cytoplasmic granules, and they stained first; that their molecular death then set free some auxetics within the cell; and that this caused 
the cell to divide until that division was arrested by total death on the staining of the centrosome. But the red blood-corpuscles could not be induced to divide on such jellies.

In the paper before quoted (3) it was noted that healthy erythrocytes, when examined on coefficient jelly which contains salts and stain, show-in about one in every hundred corpuscles-a slight granulation. These granules are scattered irregularly inside the cell, and they stain at the same time and under the same conditions as the granules of leucocytes; they give the chromatin reaction. These granular red blood-corpuscles correspond to the punctate or granular basophilia described by many pathologists. By the older fixed-film methods of blood-examination the granules would sometimes give the chromatin reaction, or more commonly would stain (say, by Leishman's method) a pale blue, contrasting with the eosin-coloured normal erythrocyte.

In the book already referred to (1) it was stated that in cases of cancer these granular cells were considerably increased in numbers and that the numbers of their granules in individual cells were increased too until in certain erythrocytes there appeared conglomerate masses of granules packed together in the centre of the cell. By the jelly method these granules could be easily distinguished as such, but by the fixed-film method the cells appeared as nucleated red blood-corpuscles. By the jelly mode of examination it was at once seen that the so-called nucleus is composed entirely of granules packed together as described, and that there is no nuclear wall or limiting membrane. 
If the blood containing such cells is placed upon a jelly containing salts, azur dye, putrid extract of sheep's suprarenal gland (auxetic), and atropine, some of these granular cells will be seen to be in the act of division after incubation for ten minutes at blood heat. But it was doubted whether this division could be described as mitotic or amitotic. The granules were arranged in an indefinite mass in the centre of the red blood-corpuscle which was dividing simply into two halves.

The investigations into this branch of the subject have been continued, and I propose to describe the results in the present paper. It has been found that if healthy erythrocytes are placed upon a jelly having less salt content than normal saline solution, they will lake, the hæmoglobin will diffuse out through the cell-walls ; and then their cytoplasm, which consists of a very finely granular protoplasm, will diffuse out until a colourless bag remains which is evenly distended with water, and this floats on the surface of the jelly like a bladder.

It has already been shown that the protoplasm of leucocytes resembles jelly and that it liquefies on the death of the cell, which can be occasioned by the staining of the nucleus (4). Further experiments showed that red blood-corpuscles are similar in these respects to leucocytes, but that they, having no nuclei or centrosomes to stain, cannot present such signs of death. However, by varying the content of salts and stain and examining the dividing granular (nucleated) erythrocytes of anæmic blood it was found possible to demonstrate what appear to be centrosomes in such 
cells as minute pink-staining points. That they are centrosomes is believed because they only appear immediately before division occurs and also because after they stain death of the whole cell takes place and hæmolysis results. In order to produce this it is necessary to employ a great concentration of stain combined with alkali in the jelly, and to heat the specimen in the incubator at blood heat for some time-red blood-corpuscles seem to have a vitality much more resistant to these factors than leucocytes. If much stain is added to the jelly the hæmoglobin within the cells stains, and remains stained until death and achromasia occurs, and then the stain fades as the hæmoglobin passes out of the cell.

But even with this strong concentration of stain with heat and alkali-factors which increase diffusion into cells-and with the strongest auxetics, divisions could not be induced in the erythrocytes of healthy blood. Various concentrations of jelly were used containing varying contents of stain (azur), salts, alkali, and such auxetics as "globin," putrid suprarenal extract of the sheep, theobromine, theophylline, creatine, caffeine-all substances which will induce divisions in lymphocytes and leucocytes-and these combined with atropine, but without success even when subjected to various degrees of heat. The jellies used would frequently cause the lymphocytes to undergo their divisions, but the red corpuscles remained unaffected. Even the granular cells, which in cancer cases sometimes divide, remained unmoved.

Early last year an attempt was made to induce $4^{*}$ 
divisions in red cells by means of a solution of hæmoglobin which had been rendered thermostable by the action of pancreatin; then it was noticed that, although the jelly containing the filtrate of such hæmoglobin (globin?) induced no change in the cells of healthy blood, the granular cells from a case of secondary anæmia at once began to divide when a high concentration of stain was added to the jelly.

This jelly was prepared as follows : 5 c.c. of a 2-per-cent solution of agar in water boiled and filtered. To this was added 1 c.c. of normal saline solution and 0.3 c.c. of a 5-per-cent solution of sodium bicarbonate in water. A solution of blood was made in a test-tube consisting of equal parts blood and water. The corpuscles were laked and the hæmoglobin set free in the water. To this was added a gramme of pancreatin powder (Fairchild) and the test-tube kept at blood heat for twentyfour hours. The solution of hæmoglobin was then filtered, and the filtrate boiled and filtered again. 1 c.c. of this second filtrate was added to the jelly with 1 c.c. of azur II stain in a 2-per-cent solution. The whole jelly was then made up to a volume of 10 c.c. with water, and when molten a drop was poured on to a microscope slide and allowed to set in a thin film. A drop of blood from a healthy mammal was placed on a coverslip and dropped on the surface of the set jelly, and the slide incubated for ten minutes. When examined under the microscope the cells were well spread out. Many of the leucocytes were burst, while others had their granules stained a deep blue. In many of the leucocytes also 
the nuclei were stained a deep blue and the lymphocytes exhibited their ring-shaped centrosomes (nucleoli) darkly coloured either in or near the nucleus. In about one in every hundred of the erythrocytes there were seen the granules, already described, stained-the amount of granulation varying in individual cells. If such a specimen is watched it will be noticed that some of the red cells gradually hæmolyse-they become pale and then fade as the hæmoglobin diffuses out through the cell-wall. This will occur in some of the cells only; and should any of them possess granules, the granules will remain stained for some time after the hæmoglobin has disappeared-the granules showing up stained through the wall of the colourless bladder. If the specimen is incubated longer, many of the red cells will take up the stain, which seems to combine with their hæmoglobin. The degree of staining varies in individual cells-perhaps with their age or with their content of oxygen. But although auxetics in such a jelly may induce divisions in leucocytes and lymphocytes, they will not produce divisions in healthy red cells, granular or otherwise, even when under similar conditions of environment.

But if instead of healthy blood, that of an animal suffering from severe secondary anæmia was placed upon such a jelly and incubated, then those erythrocytes which were highly granular would be seen in the act of division after the incubation of ten minutes; but these divisions can only be seen in those cells which possess a number of granules packed in the centre. 
It has already been shown (1) that in cancerous cachexia and in many conditions of anæmia the blood-cells show a lowered coefficient of diffusion. It has also been observed that extracts of dead tissues when mixed directly with blood-cells causes them in a like manner to show a lowered coefficient of diffusion. Experiments with blood-cells in several diseases, i.e. the secondary anæmias of malaria, endemic cirrhosis of the liver, trypanosomiasis in mammals, the anæmia of guinea-pigs accompanying infection with the lymphocytozoon of Hunter and Goldhorn-indeed, any disease producing secondary anæmia in mammals-show that the reduction of the coefficient of diffusion accompanying such anæmias is also accompanied by an increase in the number of granular cells; also there is an increase in their individual granulation until a stage is reached when the cells are packed with granules in a compact body-such cells, when fixed and stained by the Romanowsky, Jenner, or Leishman's stain, show the well-known characters of the nucleated red blood-corpuscle. If such cells are placed on auxetic jelly, as that described above, these highly granular cells will develop centrosomes and will divide into two, three, four, or six daughter cells according to their size, the degree of anæmia, and the amount of auxetic diffused into them during the experimental ten minutes' incubation. If there is much alkali solution present in the jelly and the auxetic diffuses very rapidly into the cells, some of them may show asymmetrical divisions in consequence.

A study of the phenomena of division induced in red blood-corpuscles in the secondary anæmias 
supplies the suggestion that the granules in the granular cells increase in number under the influence of the auxetic. Instead of the normal scattered granules in 1 per cent of the total erythrocytes, 15,20 , or even 30 per cent of the cells may be granular. These individual cells may also vary in anæmic conditions from the normally scattered chromatin to the condition of a mass of packed granules known as the nucleated red blood-corpuscle or erythroblast. At a further stage induced by the auxetic in these highly developed cells a centrosome appears. This is a minute body which is not always easily seen in mammalian blood, but which is readily demonstrated in the corpuscles of birds and reptiles when examined by the jelly method. These centrosomes stain on the death of the cell and differ from the other granules by their pink reaction to azur; while the granules stain a deep blue.

When division of the highly granular cell occurs the centrosome divides and one half passes towards each pole. In extreme anæmias the centrosomes divide into two, three, four, or six according to the number of daughter cells to be produced. Then the granules separate into masses-one for each daughter cell; and lastly the cell itself divides, each daughter cell then passing through the reverse process, the centrosome disappearing, the granules diminishing in numbers, until there remains the normal red blood-corpuscle containing its finely granular cytoplasm and hæmoglobin. Such is the process of cell-division in erythrocytes as watched by the jelly method of examination. 
What appears to be the centrosome having been recognised by this method of demonstration, it remained to show it by the fixed-film method of observation. A very anæmic blood was chosen -one taken from an animal dying of trypanosomiasis-and this was stained carefully by Giemsa's method. In some of those cells which showed the punctate basophilia (granular erythrocytes) a minute red-staining dot could be distinguished which coincided with the centrosomes seen during division induced in these erythroblasts by the jelly method. These centrosomes when stained in anæmic-blood fixed films-and they can be found in any form of extreme anæmia-must bear a great resemblance to those chromatic points described variously by authors as solitary parasites, or infective granules, or artefacts. But by the jelly method they are readily distinguished. Sometimes if the index of diffusion of the jelly is high, e.g. when there is much more alkali solution in it, or when it contains a little 1-per-cent morphia solution, a condition of vacuolation is induced in lymphocytes, leucocytes, blood-plates, and erythroblasts. If stain is present in the jelly these vacuoles stain red like the centrosomes; but if the vacuoles are watched they grow in size and numbers, and can thus be readily differentiated from the true centrosomes; and as the cells die and the cytoplasm liquefies such vacuoles burst.

The number of granules passing into each of the daughter cells is dependent upon the rapidity with which the process of division is produced; this again depends upon the amount of auxetic 
diffusing in ; and this in turn is dependent upon the index of the jelly, the temperature, and the readiness of the cell for division. Until a cell has developed a sufficient number of granules and a centrosome it cannot be induced to divide under any circumstances devised up to the present. But if the cell is prepared to divide, and then division is induced very rapidly, the division may be asymmetrical, i.e. the number of granules passing into one daughter cell may be much fewer than into the other. In very anæmic conditions perhaps one daughter cell may only receive 10 granules, while the remainder may receive 30,40 , or 60 each-but it is rarely possible to count accurately these granules, as they are so small and so tightly packed together; and the total number of granules possessed by one dividing erythrocyte frequently differs from that in another. The asymmetrical division in lymphocytes induced by rapid auxetic action has already been described (1), and erythroblasts seem to be subject to the same law. In lymphocytes the cytoplasmic (Altmann's) granules join together to form bodies resembling-so far as their visible functions in mitosis are concerned-chromosomes ; but in the red blood-corpuscles this coalescence apparently does not occur.

Yet all attempts to induce divisions in erythrocytes taken from healthy blood-even in the granular cells-have failed. Only in the blood of animals suffering from secondary anæmia or from pernicious anæmia did the divisions occur, and then only in the highly granular cells. But it was remembered that in states of cancerous 
cachexia and other forms of secondary anæmia the cells in the peripheral blood invariably show a diminished coefficient of diffusion as measured in the way described (3).

An attempt was made therefore to reduce the coefficient of healthy erythrocytes artificially, and then to subject them to the influence of strong auxetics such as putrid extract of sheep's suprarenal gland, "globin," and azur. The reduction of the coefficient of the healthy cells was brought about by adding to the jelly only that amount of salts which would just prevent the erythrocytes from laking, and keeping them thus at the verge of hæmolysis. The jelly was made as follows : 5 c.c. of a 2-per-cent solution of agar in water boiled and filtered. To this was added 1 c.c. of a 2-per-cent solution of azur II, 1 c.c. of putrid extract of suprarenal gland, 1 c.c. of a solution of "globin," and 0.3 c.c. of a 5-per-cent solution of sodium bicarbonate. This jelly was mixed in a test-tube, and while still molten water was added until it arrived at such a degree of dilution which when tested with living erythrocytes would just prevent them laking after exactly ten minutes' incubation.

When mammalian blood from a case of secondary anæmia was placed upon such a jelly and incubated it was noticed that many of the red cells died at once, some showed deeply stained hæmoglobin, while many remained unchanged; but it was also noticed that the granular cells were more numerous than those on a control jelly which contained ample salts-the control being made from the same blood. It was noticed that the 
granular cells had become very granular, and the very granular ones were in the act of division, exhibiting centrosomes, and dividing into two, three, four, or six, according to the degree of naæmia. The actual daughter cells, however, varied also in numbers in individual cells of the same specimen, some cells dividing into two, three, and so on; but the greater the anæmia, the greater the average number of the daughter cells.

Still, the blood-corpuscles from a healthy man placed upon such a jelly showed no change. Even when the healthy erythrocytes were repeatedly washed in a saline solution which kept them exactly at the borderland of death they were uninfluenced by its action. No amount of auxetic or reduction of their coefficient of diffusion would induce divisions in healthy red blood-corpuscles. But if the corpuscles are altered by the cause of secondary anæmia, then they will show increased granulation, and the highly granular ones will divide as the auxetic acts upon them.

It has been shown (1) that blood-serum will inhibit the action of auxetics on leucocytes and lymphocytes when added to the molten jelly. It seemed possible that it was the presence of the serum which prevented the healthy corpuscles being influenced by them also. But repeated washing of the corpuscles in saline solution must free them from some of the serum, yet they would not divide. Only in conditions in which the blood is altered from the normal will the granular erythrocytes divide in responsè to the action of 
auxetics; and then only will those granular cells divide which have developed centrosomes.

But highly granular erythrocytes (nucleated red blood-corpuscles) taken from the internal organs of healthy mammals will divide in the same manner as similar cells taken from the peripheral blood in cases of anæmia.

One point is of great interest. The size of the granular erythrocytes (erythroblasts, normoblasts, megaloblasts, gigantoblasts) seems to be an indication of the number of daughter cells to which they give rise. And the more numerous the larger cells are, therefore, the greater the degree of the regenerative process, and probably also the degree of the anæmia. In conditions of extreme anæmia the granular erythrocytes commonly divide into six daughter cells. In the blood from internal organs of healthy persons the granular red blood-corpuscles usually divide into two only. In the blood of cases of secondary anæmia, therefore, there must be present, in the peripheral blood, much free auxetic, probably globin and creatine, and there must also be a considerable reduction in the coefficient of diffusion in each individual cell. A similar condition must also be present in the internal organs in health, and this is known to be the case post mortem, for a jelly which will cause lymphocytes taken from the finger to divide will kill the same cells if taken from the portal vein. But it has not been found possible so to reduce the coefficient of healthy red cells from the peripheral blood artificially as to cause them to divide.

One interesting fact has been learnt by these 
experiments. When lymphocytes from the peripheral blood or elsewhere are placed on a suitable jelly containing auxetics and incubated they divide-they must divide. But erythrocytes will not divide until they have reached a certain development. Therefore another factor is required for them in addition to the presence of auxetics-it is maturity. Unless a cell is mature it will not divide. But if the erythrocyte is mature and is placed under the power of an auxetic it will-indeed must-divide.

Lastly, it must be realised that the serum in which they are bathed has the power of retaining the height of the coefficient of diffusion of bloodcells; and this power seems to be dependent upon the salt content of that serum. The coefficient of diffusion of a certain cell therefore varies, within certain limits, with its environment, and the variation of the environment seems to be the variation of its density.

\section{REFERENCES}

(1) Induced Cell-Reproduction and Cancer, Hugh C. Ross and J. W. Cropper. Murray: London, 1910.

(2) "A Report on Cancer Research," Hugh C. Ross and C. J. Macalister. The British Medical Journal, October 23, 1909.

(3) "The Coefficient of Diffusion," H. C. Ross. Proceedings of the Royal Society. B. Vol. 81, 1909.

(4) "On the Death of Leucocytes," H. C. Ross. Journal of Physiology, September 1908. 
PRINTED $\mathrm{BY}$ HAZELL, WATSON AND VINEY, LD, LONDON AND AYLESBURY.

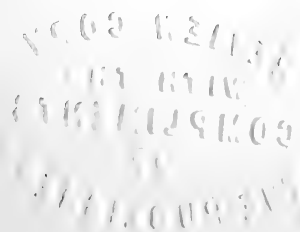



a A Q9.

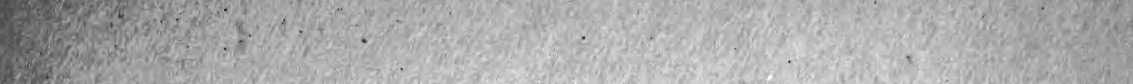

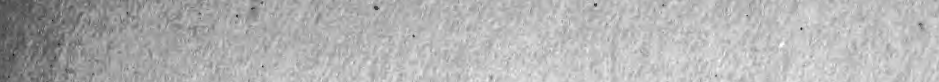

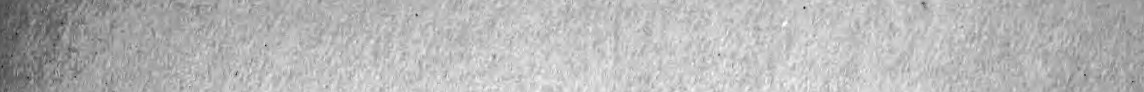

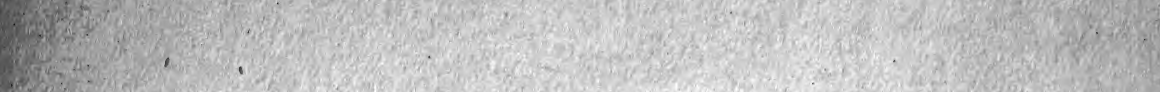

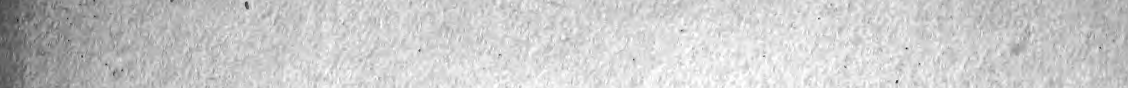

6.9.8.

(n)

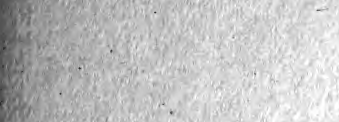

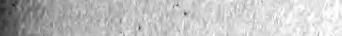

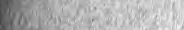

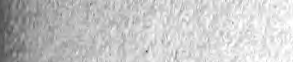

$x^{3} x^{2}$

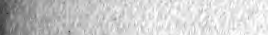




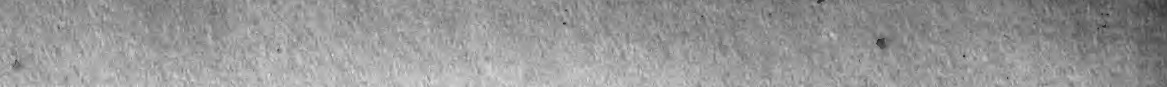

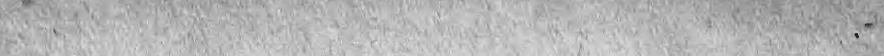

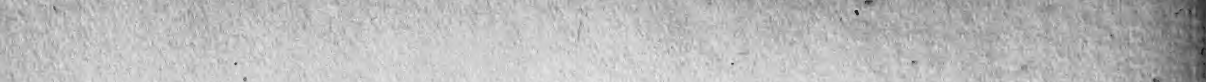
Wate W.

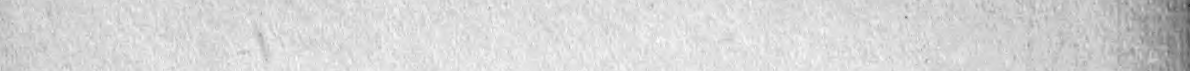

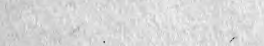




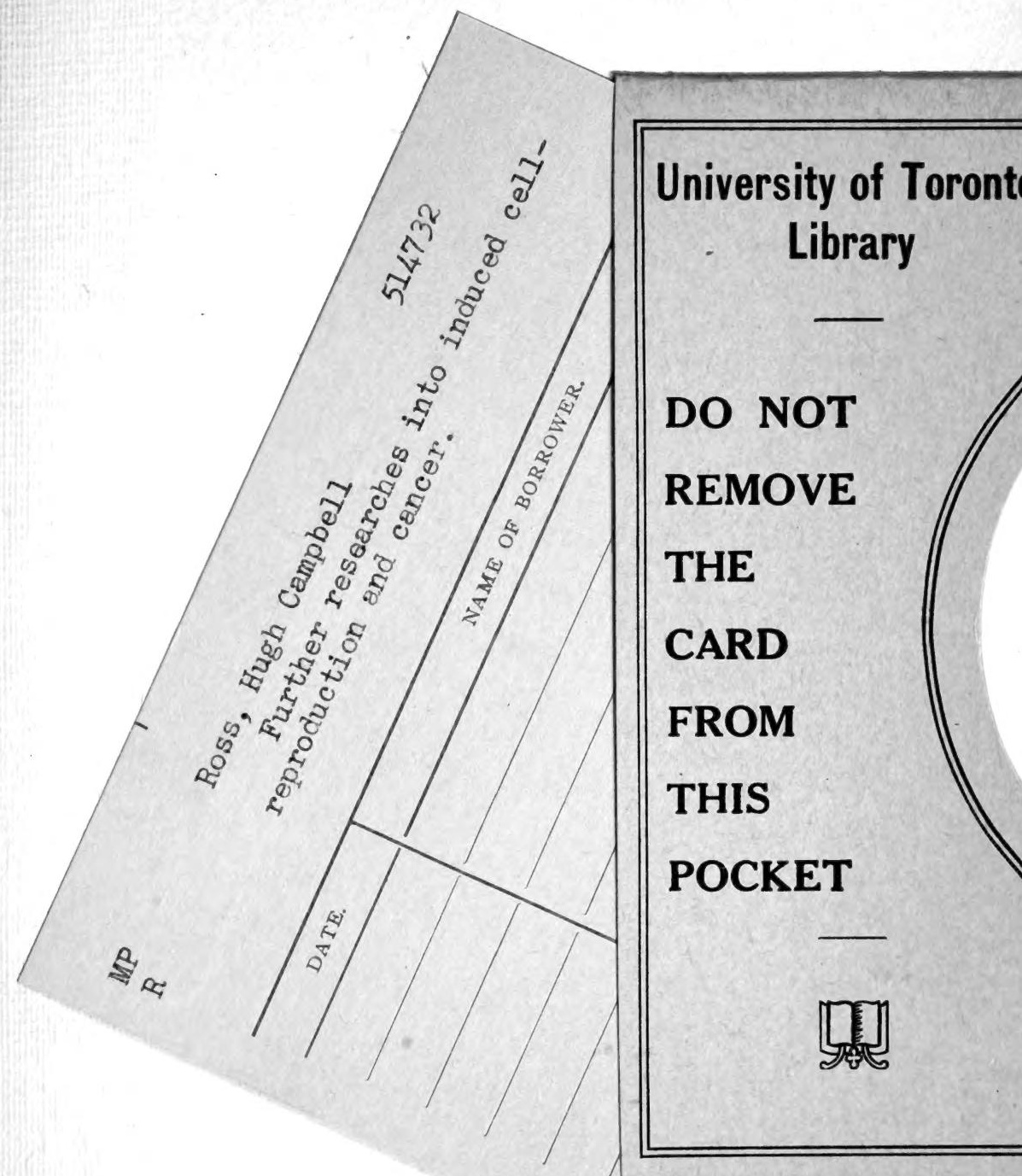




\%

\%

W

\%

-

W

W

\%

\%

\% 